\title{
Correction to: Genetic diversity in potato mop-top virus populations in the United States and a global analysis of the PMTV genome
}

\author{
Ying Zhai • Ipsita Mallik • Aflaq Hamid • \\ Afsha Tabassum • Neil Gudmestad • \\ Stewart M. Gray • Hanu R. Pappu
}

Published online: 16 December 2019

(C) Koninklijke Nederlandse Planteziektenkundige Vereniging 2019

\section{Correction to: Eur J Plant Pathol}

https://doi.org/10.1007/s10658-019-

01836-6

Co author name misspelt and should read as Stewart Gray.

The online version of the original article can be found at https://doi.org/10.1007/s10658-019-01836-6

Y. Zhai · A. Hamid · A. Tabassum · H. R. Pappu $(\bowtie)$ Department of Plant Pathology, Washington State University, Pullman, WA, USA

e-mail: hrp@wsu.edu

I. Mallik · N. Gudmestad

Department of Plant Pathology, North Dakota State University, Fargo, ND, USA

S. M. Gray

Emerging Pest and Pathogens Research Unit, USDA, ARS, Ithaca, NY, USA

Present Address:

A. Hamid

Department of Plant Pathology, Sher-e-Kashmir University of Agricultural Sciences \& Technology of Kashmir, Shalimar, Srinagar, J\&K, India

Present Address:

A. Tabassum

Department of Plant Pathology, University of Georgia, Tifton, GA, USA 